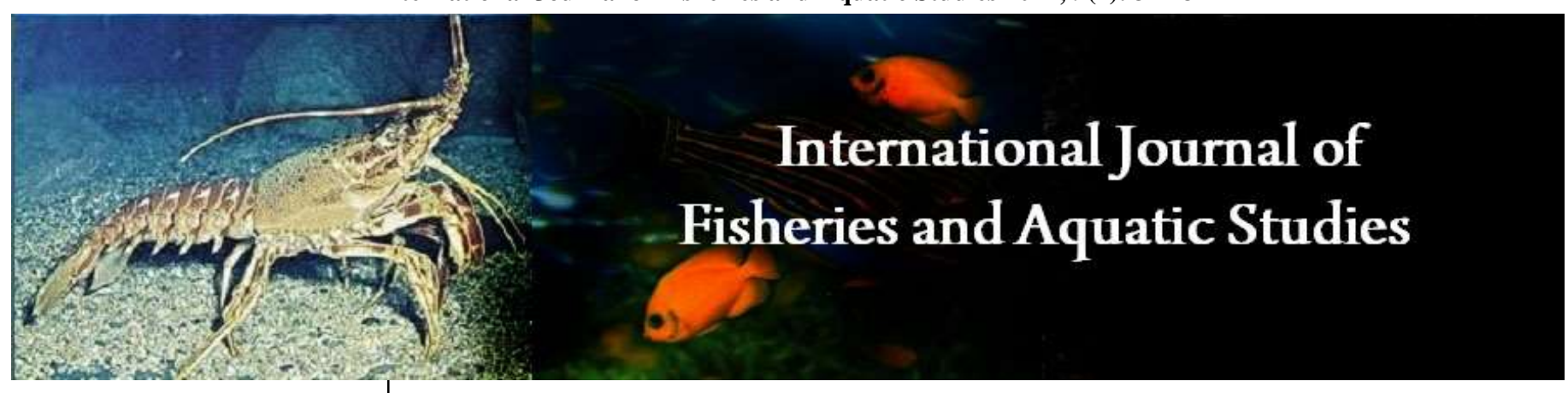

E-ISSN: 2347-5129

P-ISSN: 2394-0506

(ICV-Poland) Impact Value: 5.62

(GIF) Impact Factor: 0.549

IJFAS 2021; 9(1): 322-327

(C) 2021 IJFAS

www.fisheriesjournal.com

Received: 23-11-2020

Accepted: 25-12-2020

Elagba Ha Mohamed

Institute of Environmental

Studies, University of

Khartoum. P.O. Box 321,

Khartoum, Sudan
Corresponding Author: Elagba Ha Mohamed Institute of Environmental Studies, University of Khartoum. P.O. Box 321, Khartoum, Sudan

\section{Observed impact of climate change on abundance and distribution of Nile fish in Sudan during the period (2001-2020)}

\author{
Elagba Ha Mohamed
}

DOI: $\underline{\text { https://doi.org/10.22271/fish.2021.v9.i1d.2419 }}$

\begin{abstract}
A reduction in species of Nile fish was observed during (2001-2020). Annual temperature revealed high levels $\left(29\right.$ to $31{ }^{\circ} \mathrm{C}$ ), with fluctuation between 2001 and 2008, decreased from 2009 to 2000. Rainfall fluctuated between 2001 and 2007, with highest peaks in 2019 and 2020. Positive correlation $(r=$ 0.34402) was found between temperature and catch. Catch increased with decreased temperature. Negative correlation $(r=-0.15869)$ was found between catch and rainfall, high level of catch was recorded with low rainfall. The results indicated changing in climate within Sudan over time. To tolerate climate change for the next twenty years, the Nile fish will either modify their body structure and function, or even stand the risk and extinct from the Nile. Future changes in the productive capacity of the Nile need effective and progressive responses to the urgent threat of climate change, through mitigation and adaptation measures and sustainable management practices.
\end{abstract}

Keywords: Climate change, impact, Nile fish, Lake Nubia, rainfall, Sudan, temperature

\section{Introduction}

Climate change could be one of the main threats faced by aquatic ecosystems and freshwater biodiversity. Improved understanding, monitoring and forecasting of its effects are thus crucial forresearchers, policy makers and biodiversity managers. Climate change poses new challenges to fisheries and aquaculture with serious implications for people who depend on them for their livelihoods, the world's poorest people, and the billion for whom fish is an important source of animal protein ${ }^{[1-5]}$. Climate change is expected to alter the hydrological processes of water available for fish and is a great threat to fish production ${ }^{[6-8]}$. Projections of future conditions show further impacts on the distribution and abundance of fishes associated with a relatively small temperature change. Global atmospheric temperatures have risen throughout the last 50 years ${ }^{[9]}$, with increase of about $0.8{ }^{\circ} \mathrm{C}\left(1.4^{\circ} \mathrm{F}\right)$ in the global average surface temperature. Regional increases in temperature have been documented in the southwest Pacific Ocean and North Atlantic Ocean ${ }^{[10]}$. The western Mediterranean Sea temperatures have also been rising ${ }^{[11]}$, which was reflected in the presence and abundance of ectothermic marine life ${ }^{[12]}$. Two thermophilic algal species, several thermophilic echinoderm species, and some thermophilic fishes have increased in abundance, off the coast of France.

The freshwater fisheries of Sudan are based on the River Nile and its tributaries which contribute over $90 \%$ of the estimated production potential of the country. The man-made lakes on the White Nile, the Blue Nile, Atbara River and the main Nile River and Lake Nubia on the main Nile count as the major fishing localities with respect to fish resource magnitude and exploitation. Although the fishery sector's contribution to national income in Sudan is small (i.e. $0.4 \%$ of gross domestic product), fishing is the source of employment and livelihood for large communities ${ }^{[13,8]}$. Climate change effects, such as increased temperature and rainfall, is expected to bring shifts in the distribution of Nile fish stocks, with some areas benefiting while others lose out.

Changing fish distributions and abundances will undoubtedly affect communities of humans who harvest these stocks. Change in fish stocks will also impact the subsistence, commercial and recreational harvesters negatively or positively, and this impacting will continue on fish and fisheries ${ }^{[14,15]}$. Primary production in freshwater lakes has been observed to decrease in Lake Tanganyika in the tropics ${ }^{[16]}$, but increase in some Arctic ${ }^{[17]}$ and boreal lakes. 
In both cases the changes were attributed by the authors to climate change ${ }^{[18]}$. The leading factors of climate change include increase in mean air temperature, shifting precipitation patterns, and an increase in extreme weather events. Since fish are poikilothermous, one of the leading factors is the temperature of the surface layers of the water, and there is a very close correlation between the catches of such species and the temperature ${ }^{[19]}$.

Recently, Sudan's fisheries production revealed great fluctuations ranging between $(28000$ - 72000) tons, with a sharp decrease in last the quarter of the twentieth century. A reduction in available species of the Nile fish was also observed. Based on these problems, the study is set to assess effects of climate change, temperature and rainfall on the total production freshwater of fisheries and the abundance of fish species in the main fish sources of the Nile in Sudan, as well as to outline the management options of climate change that will protect the aquatic fauna. The hope for sustainable fish production in Sudan need to sensitize fishermen on the imminent hazards of persistence water scarcity and poor quality as evidence of climate changes that could affect fish production.

\section{Material and Methods}

The present research basically adopted a library search design of reviewing literatures of climate change impact on aquatic lives globally. Local data of annual fish production and abundance of fish species was collected from the records of the Federal Ministry of Animal wealth and Fisheries for the period 2001 to 2010. For more comparison and investigation data of fish production for the period 1981 to 2000 was also considered. Meteorological data on rainfall and temperature for the period 2001-2020 was extracted from the meteorological records of the Metrological Unit of Sudan. To investigate the impacts of climate change, temperature and rainfall on total catch for the period (2001-2020), the statistical program ${ }^{[20]}$ was used.

\section{Results}

Many species of the Nile fish disappeared from catch in both main Nile River and Lake Nubia, and twenty species of fish were not caught from Lake Nubia in the last years (Figure 1). This reduction likely a result of climate changes that affects the normal aquatic conditions of the Nile fish and hinders the reproduction activities and survival of these species.

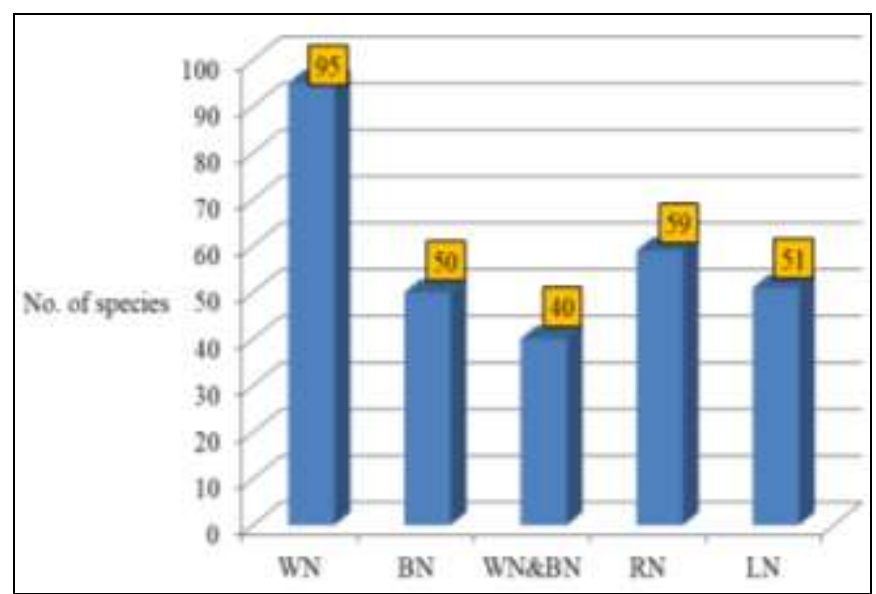

Fig 1: Occurrence of Nile fish in main resources. (Source: Federal Ministry of Animal Wealth and Fisheries, Sudan).

As shown in (Figure 2), a high level of total catch, which continued from the previous decade with some fluctuations, was recorded at the beginning of the 2000 century, but a dramatic reduction was detected in the last nine years (20142020).

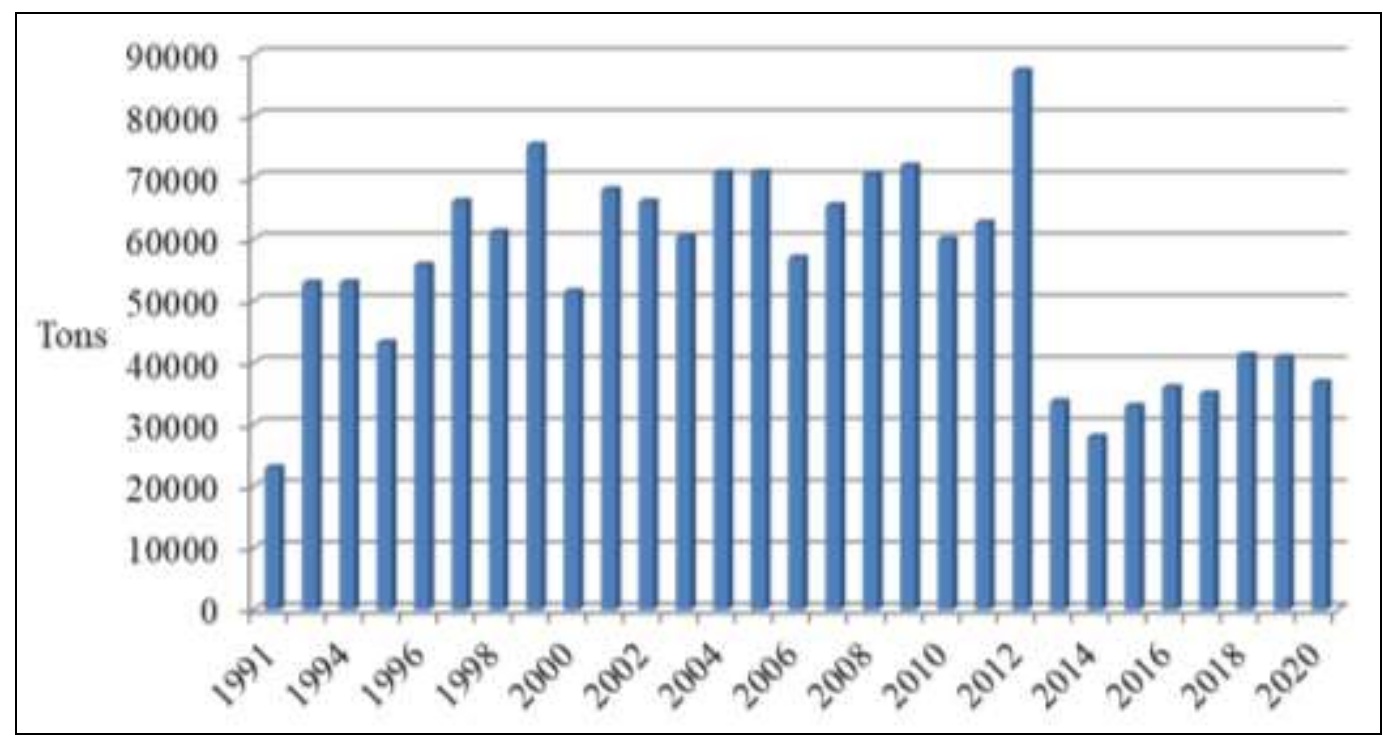

Fig 2: Total catch of Nile fish in Sudan during the period (1991- 2020).

Statistical analysis revealed positive linear correlation with $(r$ $=0.34402$ ) between the levels of annual temperature and total fish catch, where, catch increased with decreased temperature, as shown in (Figure 3), although the opposite was observed in some years. On the other hand, no linear correlation $(r=-$ 0.15869) was found between the total catch and rainfall
(Figure 4), although a high level of catch was recorded when there was low rainfall during the period (2001-2010). However, according to analysis no correlation (-0.26599) was found between the annual temperature and rainfall during this period (Figure 5). 


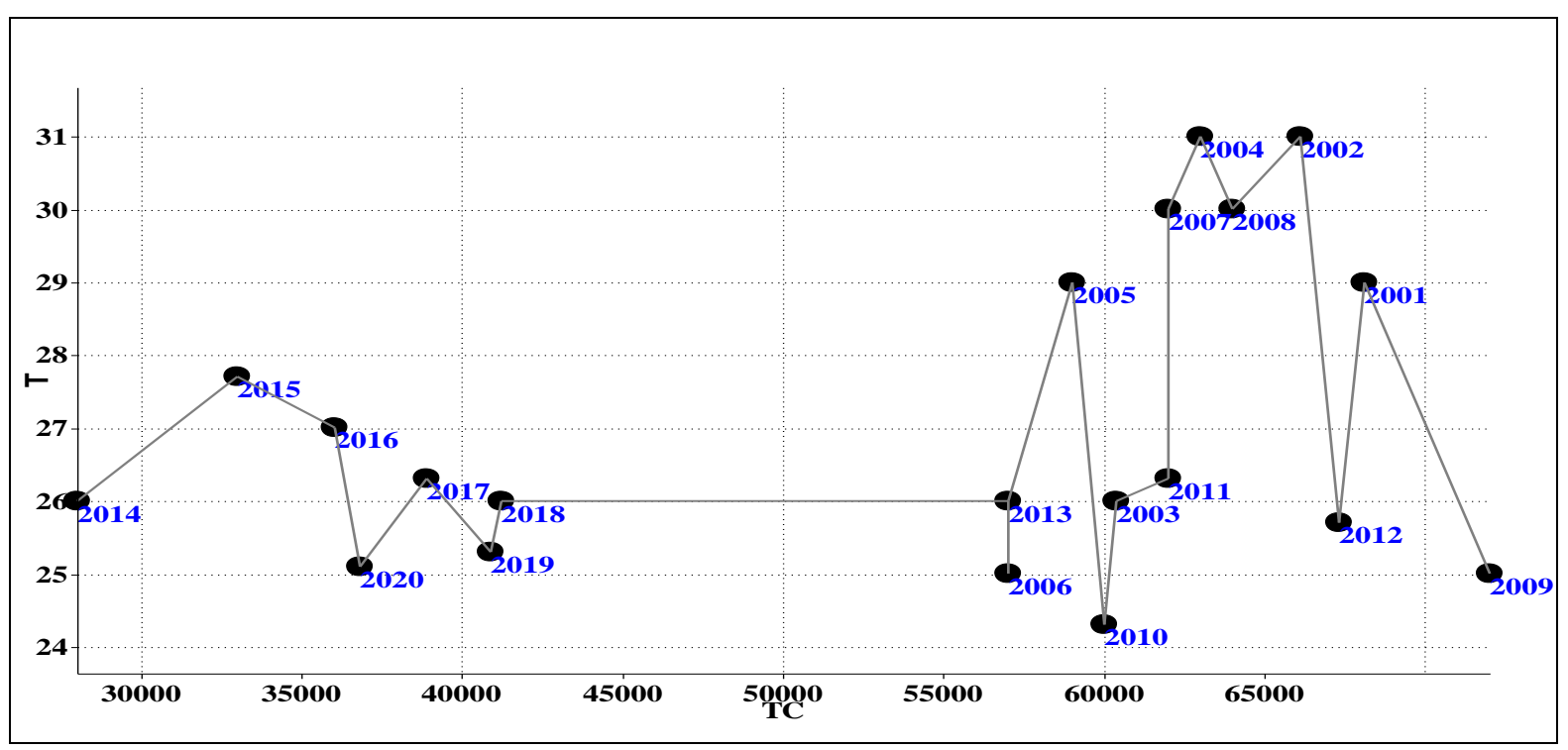

Fig 3: The correlation between total catch of Nile fish and annual temperature during the period (2001-2020)

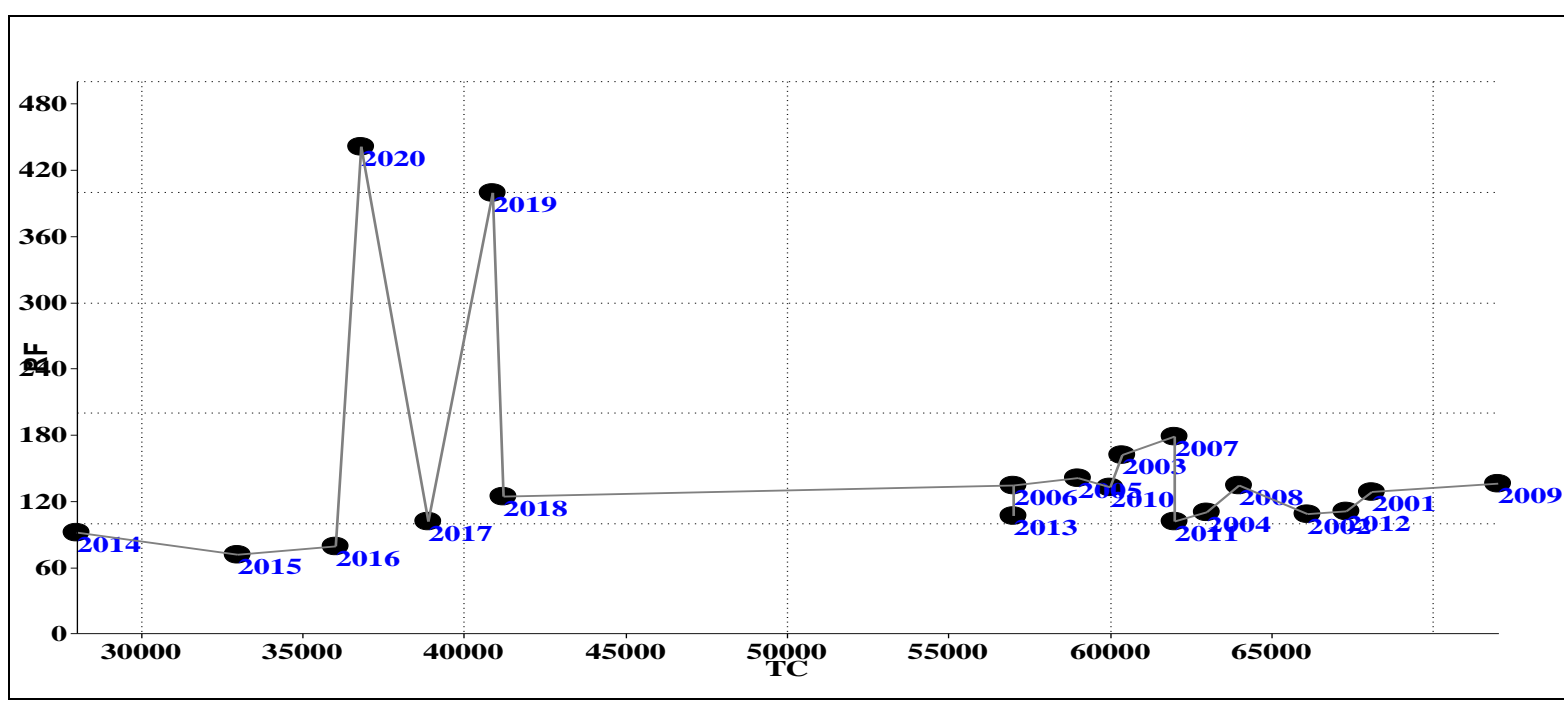

Fig 4: The correlation between the total catch of Nile fish and rainfall during the period (2001-2020)

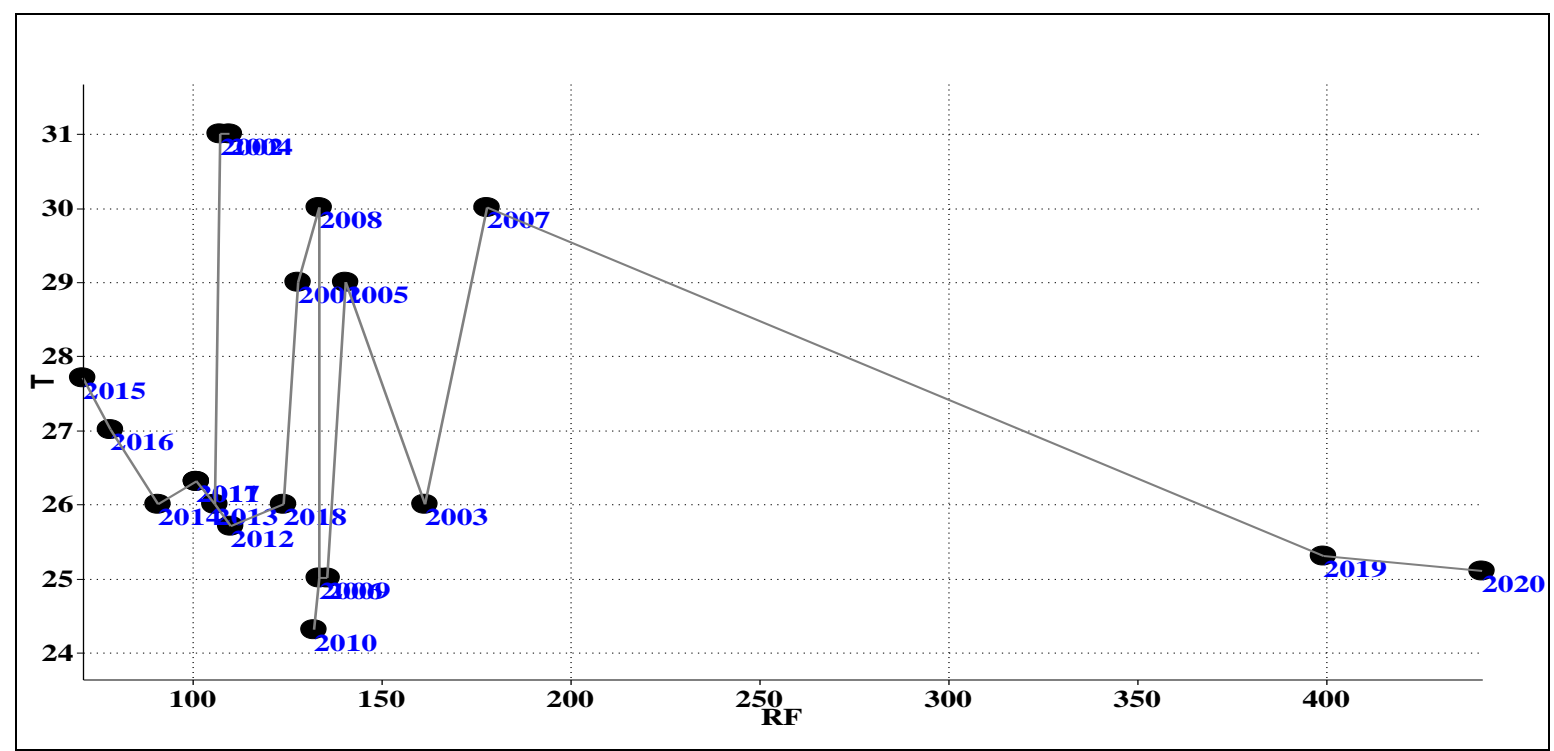

Fig 5: The correlation between the annual temperature and rainfall in Sudan during the period (2001-2020)

\section{Discussion}

The present results reflect a clear effect of climate change on the Nile ecosystem, and the abundance of fish species in the
Nile water. Freshwater environments and their fishes are particularly vulnerable to climate change because the persistence and quality of aquatic habitat depend heavily on 
climatic and hydrologic regimes. The relationship of rainfall and total catch was not consistent throughout the twenty years. In some years the catch increased when rainfall decreased and in others decreased when rainfall increased. The decline in availability of fish species is could be due to modification in the normal habitat of the Nile fish, and that likely affected the productivity of the ecosystem and fish stocks. Impacted species have evolved physiologically to live within a specific range of environmental variation, and existence outside of that range can be stressful or fatal [21]. Climate change affects individuals, populations and communities through the individuals' physiological and behavioral responses to environmental changes. Climate change was found to seriously threat the persistence of many of Australia's freshwater fish species, especially of those with limited ranges or specific habitat requirements, or of those that are already occurring close to physiological tolerance limits [22].

Extremes in environmental factors, such as elevated water temperature, low dissolved oxygen or salinity, and $\mathrm{pH}$, were reported to have deleterious effects on fishes ${ }^{[23]}$. In many regions, climate change is affecting precipitation and melting of snow and ice, altering the hydrological systems and the quantity and quality water resources [14]. Such impact of climate change was recorded in freshwater fish, marine and estuarine fishes and fisheries ${ }^{[20]}$.

On the other hand, comparison between the annual temperature and the total fish catch during (2001-2020) revealed a positive correlation $(r=0.34402)$ where, catch increased with decrease in the temperature. A fluctuation in fish landings have increased and decrease at the beginning of the twentieth century with a range of 57000 to 72000 tons, but a dramatic decline in temperature and decline in catch was observed during the last eight years of twentieth century. The main aspect of global climate change is the magnitude of the impact of a relatively small temperature change. An increase of a few degrees in atmospheric temperature will not only raise the temperature of the water, but also cause major hydrologic changes affecting the physical and chemical properties of Nile water. This will lead to changes in fish, invertebrate, and plant of the Nile communities that evolved in similar habitats ${ }^{[25]}$. The temperatures of the western Mediterranean Sea have been rising for the last 20-30 years, which is reflected in the presence and abundance of ectothermic marine life [14]. At the global level, the earth's average surface temperature has increased by more than 0.8 ${ }^{\circ} \mathrm{C}$ since the middle of the nineteenth century, and is now warming at a rate of more than $0.1{ }^{\circ} \mathrm{C}$ every decade $[26,27,28]$, with more dramatic consequences for freshwater systems than for oceans because of their shallowness and lower buffering capacity. Seawater temperatures have risen dramatically since the 1970s, and subsurface pulses of relatively warm water of Atlantic origin have been detected all around the Eurasian basin ${ }^{[29]}$. Heat waves are more frequent now, even though the reliability of data and level of certainty vary across continents [30]. The impact of climate change is expected to influence fish supply, income and nutrition in countries more dependent on fisheries and which could be vulnerable [31, 32, 33]. The reduction and extinction in species may affect the accessibility to fish resources and consequently the nutritional habits of the local communities, exporters and consumers ${ }^{[34,}$ 35, 36], suggested that there is already a dietary shift to less animal-based products and to more fruit and vegetables.

The level of dissolved oxygen is known to decrease with increased temperature. Fish need $10 \%$ more oxygen for $1{ }^{\circ} \mathrm{C}$ rise in temperature ${ }^{[37,38]}$. The present results indicated the effects of climate change on the distribution of freshwater fish. In a study conducted by [39] on qualitative and quantitative analyses of multi species, to find out whether the observed responses of freshwater fish to recent changes in climate are consistent with those predicted under future climate scenarios, the authors confirmed that freshwater fishspecies could be severely affected by contemporary climate change, and observations and predictions are quite correlated, thus supporting the reliability of future projections. However, the natural and anthropogenic factors such as green house gases and burning of fossil fuels are the causes of global warming, and are the likely ultimate causes of ongoing deoxygenation in many parts of the open ocean [40, 41]. Many substantial predicted biological and socio-economic impacts on tropical fisheries would be prevented if greenhouse gasmitigation actions keep global atmospheric warming below $1.5^{\circ} \mathrm{C}$ relative to pre-industrial levels ${ }^{[42]}$.

On the one hand, water which is vital to the survival of ecosystems, plants and animals that lives in them are being threatened; and as such reduces the species of fish caught, and the quantity and quality of water that is available for the inhabitants ${ }^{[36,43]}$.

\section{Conclusions}

The contribution of fisheries to the GDP of Sudan is currently marginal although, the country is endowed with water resources and lands that can support vigorous capture fisheries and aquaculture. However, global climate change is impacting and is likely increasingly impact the Nile fish and fisheries. The present study reflected the effects of climate change on number of species available in the main resources of the Nile fish and the change in annual total catch. Positive correlation was found between annual temperature and total catch, while more catch was recorded when there was low rainfall during the period (2001-2010). The results reflect negative impacts of climate change on the Nile ecosystem and vulnerability fishing populations to climate change. Changing fish distributions and abundances will undoubtedly affect the communities of Sudanese who harvest these stocks for subsistence and commercial purposes. Future changes in the productive capacity of the Nile need effective and progressive response to the threat of climate change, through mitigation and adaptation measures and sustainable management practices. Basic and deeper information on the physiology and ecology of the Nile fish are needed to enable researchers to more accurately predict the future effects of climate change on fish species and their harvesters. The hope for sustainable fish production in Sudan also needs sensitizing fishermen on the imminent hazards of persistence water scarcity and poor quality as evidence of climate changes that could affect fish production. Human responses to climate change should be proactive and focus on maintaining population resilience through the protection of habitat, mitigation of current anthropogenic stressors, adequate planning and provisioning of environmental flows. Laws and sustainable management of fisheries resources and the fish habitat practices with the help of scientific knowledge should be enforced and adequate financial resources and human capacity to implement fisheries program should be provided with improvement of the socioeconomic status of fishermen. However, in an attempt to address climate change and related issues, Sudan has already ratified the United Nations Framework Convention on 
Climate Change (UNFCCC) in 2003 and submitted its initial national communication the same year.

\section{Acknowledgements}

The provision of fisheries data by the Federal Ministry of Animal Wealth and Fisheries, and the meteorological records of the Metrological Unit of Sudan are highly appreciated.

\section{References}

1. Klyashtorin LB. Climate change and long-term fluctuations of commercial catches: the possibility of forecasting. Fisheries Technical Paper No. 410. FAO, Rome, Italy 2001.

2. Henson R. The Rough Guide to Climate Change. Rough Guides Ltd., London 2006.

3. IPCC (Intergovernmental Panel on Climate Change). Coastal zones and marine ecosystems. In: McCarthy JJ, Canziani OF, Leary NA, Dokken DJ, White KS (Ed.). Climate Change: Impacts, Adaptation, and Vulnerability. Cambridge University Press, UK 2001, 1032.

4. Rochet MJ, Trenkel VM, Carpntier A, Cappin F, Luis GdeSm Leaute J-P et al. Do changes in environmental and fishing pressures impact marine communities? An empirical assessment. Journal of Applied Ecology 2010;47(4):741-750.

5. Food and Agriculture Organization (FAO). Assessing climate change vulnerability in fisheries and aquaculture: Available methodologies and their relevance for the sector, by Cecile Brugère and Cassandra De Young. FAO Fisheries and Aquaculture Technical Paper No. 597. FAO, Rome, Italy 2015.

6. McGinn NA. Fisheries in a Changing Climate. American Fisheries Society Symposium 32, Bethesda, MD 2002, 295.

7. Barton BA, Morgan JD, Vijayan MM. Physiological and condition-related indicators of environmental stress in fish. In: Adams SM (Ed.). Biological Indicators of Ecosystem Stress. American Fisheries Society, Bethesda, MD 2002;111-148.

8. Bene C, Heck S. Fish and Food Security in Africa. NAGA, World Fish Centre. Quarterly 2005.

9. Quay P. Ups and downs of $\mathrm{C} 02$ uptake. Science 2002;298:2344.

10. Bindoff NL, Church JA. Warming of the water column in the southwest Pacific Ocean. Nature 1992;357:59-62.

11. Bethoux JP, Gentili B, Raunet J, Tailliez D. Warming trend in the western Mediterranean deep water. Nature. 1990;347:660-662.

12. Francour P, Boudouresque CF, Harmelin JG, HarmelinVivien ML, Quignard JP. Are the Mediterranean waters becoming warmer? Information from biological indicators. Marine Pollution Bulletin 1994;28:523-526.

13. FAO (Food Agricultural Organization). Sudan fisheries country profile.FID/CP/SUD 2008.

14. Roessig JM, Woodley CM, Cech JJ, Hansen LJ. Effects of global climate change on marine and estuarine fishes and fisheries. Reviews in Fish Biology and Fisheries 2004; $14: 251-275$.

15. Vincent W, Allison E, Bell JD, Blythe J, Cheung WWL, Frolicher $\mathrm{J}$ et al. Climate Impacts on Arctic Freshwater Ecosystems and Fisheries: Background, Rationale and Approach of the Arctic Climate Impact Assessment (ACIA)". Ambio 2006;35(7):326-329.

16. O'Reilly CM, Alin SR, Plisnier PD, Cohen AS, McKee
BA. Climate change decreases aquatic ecosystem productivity of Lake Tanganyika, Africa. Nature 2003; 424(6950):766 -768.

17. Michelutti N, Wolfe AP, Vinebrooke RD, Rivard B, Briner JP. Recent primary production increases in arctic lakes. Geophysical Research Letters 2005;32(19):L19715.

18. IPCC (Panel on Climate Change). Climate change 2014: Synthesis report. Contribution of Working Groups I, II and III to the Fifth Assessment Report on the Intergovernmental Panel on Climate Change. Core writing team, Pachauri RK, Meyer LA (Eds.). Geneva, Intergovernmental Panel on Climate Change 2014, 151.

19. Biswas BK, Svirezhev YM, Bala BK. A model to predict climate change impact on fish catch in the World Oceans. IEEE Trans. System Management Cybern. Part A 2005;35(6):773-783.

20. Past. Statistical Package for Scientific analysis 2005.

21. Barton BA, Morgan JD, Vijayan MM. Physiological and condition-related indicators of environmental stress in fish. In: Adams SM (Ed.). Biological Indicators of Ecosystem Stress. American Fisheries Society, Bethesda, MD 2002;111-148.

22. Morrongiello JR, Stephen JB, James CB, David AC, David NEN, Ikedife MJK et al. Climate change and its implications for Australia's freshwater fish. Marine and Freshwater Research 2011;62(9):1082-1098.

23. Moyle PB, Cech JrJJ. Fishes: An Introduction to Ichthyology, 5th Ed. Prentice Haii, Upper Saddle River, NJ 2004, 726.

24. Attrill MJ. Community-level indicators of stress in aquatic ecosystems. In: Adams SM (Ed.). Biological Indicators of Ecosystem Stress. American Fisheries Society, Bethesda, MD 2002;473-508.

25. Elenwo EI, Akankali JA. Impact of climate change on aquatic fauna of economic importance in Niger Delta. Niger. Atmosphere and Climate Science. 2014;4:710720.

26. Brodte E, Knust R, P"ortner HO. Temperature dependent energy allocation to growth in Antarctic and boreal eelpout (Zoarcidae). Polar Biology 2006;30:95-107.

27. Hannesson R. Geographical distribution of fish catches and temperature variations in the Northwest Atlantic since 1945. Marine Policy 2007;31:32-39.

28. Hansen J, Ruedy R, Sato M, Lo K. Global surface temperature change. Reviews of Geophysics 2010;48(4):RG4004.

29. Rhein L, Arkin P, Smith TM, Shen SSP. Global precipitation trends in 1900-2005 from a reconstruction and coupled model simulations. Journal of Geophysical Research Atmospheres 2013;118(4):1679-1689.

30. Hartmann DL, Klein TAMG, Rusticucci M, Alexander LV, Brönnimann S, Charabi $\mathrm{Y}$ et al. Observations: atmosphere and surface. In: Stocker TF, Qin D, Plattner $\mathrm{G}-\mathrm{K}$, Tignor $\mathrm{M}$, Allen SK, Boschung $\mathrm{J}$ et al. (Eds.). Climate change 2013: The physical science basis. Contribution of Working Group I to the Fifth Assessment Report of the Intergovernmental Panel on Climate Change. Cambridge, UK and New York, USA, Cambridge University Press 2013;159-254.

31. Akankali JA, Jamabo NA. A review of some factors militating against sustainable artisanal fisheries development in Niger Delta, Nigeria. Asian Journal of Agricultural Sciences 2011;3:369-377. 
32. Pörtner HO, Karl DM, Boyd PW, Cheung WWL, LluchCota SE, Nojiri Y et al. In: Field CB, Barros VR, Dokken DJ, Mach KJ, Mastrandrea MD, Bilir TE et al. (Eds.). Climate change: Impacts, adaptation, and vulnerability. Part A: Global and sectoral aspects. Contribution of Working Group II to the Fifth Assessment Report of the Intergovernmental Panel on Climate Change. Cambridge, UK and New York, USA, Cambridge University Press, 2013;159-254.

33. Mohamed EHA, Ibrahim A. The impact of climate change on Nile Fish abundance and fishery landings in Khartoum state. International Journal of Fisheries and Aquatic Research 2017;2(6):11-15.

34. Barange M, Merino G, Blanchard JL, Scholtens J, Harle $\mathrm{J}$, Allison $\mathrm{EH}$ et al. Impacts of climate change on marine ecosystem production in societies dependent on fisheries. Nature Climate Change 2014;4:211-216.

35. FAO (Food Agricultural Organization). The future of food and agriculture. Trends and challenges. Rome, Italy. FAO 2017, 180.

36. Barange M, Bahri T, Beveridge MCM, Cochrane KL, Funge-Smith S, Poulain F. (Eds.). Impacts of climate change on fisheries and aquaculture: Synthesis of current knowledge, adaptation and mitigation options. FAO Fisheries and Aquaculture Technical Paper No. 627. Rome, Italy. FAO, 2018, 628.

37. Orlowski A. Influence of thermal conditions on biomass of fish in the polish EEZ. Fishery Research 2003;63:367 377.

38. Heinemann G, Bromwich DH, Gutjahr O. Extreme warming in the Kara Sea and Barents Sea during the winter period 2000 to 2016. Journal of Climate. 2017;30(22):8913-8927.

39. Lise C, Laetitia B, Martin D, Gael G. Climate-induced changes in the distribution of fresh water fish: Observed and predicted trends. Freshwater Biology 2013;58(4):625 -639 .

40. Kwiatkowski L, Laurent B, Olivier A, Philippe C, Peter $\mathrm{C}$ et al. Emergent constraints on projections of declining primary production in the tropical oceans. Nature Climate Change, Nature Publishing Group 2017;7(5):355-358.

41. Breitburg D, Lisa AL, Andreas O, Marilaure G, Francisfico P, Daniel JC et al. Declining oxygen in the global ocean and coastal waters. Science 2018;35(6371):1-13.

42. Lame VWY, Edward HA, Johann DB, Jessica B, William WLC, Thomas LF et al. Climate change, tropical fisheries and prospects for sustainable development. Nature Reviews Earth \& Environment 2020;(1):440-454.

43. FAO (Food and Agriculture Organisation). The state of world fisheries and aquaculture. Meeting the sustainable development goals. Rome, Italy. FAO 2018. 